\title{
Poza nachylenie tekstowe, w stronę doświadczenia przedtekstowego. Wskazówki terapeutyczne
}

Grzegorz Godlewski

TEKSTY DRUGIE 2018, NR 1, S. 61-78

DOI: $10.18318 /$ td.2018.1.4

\section{Dziedzictwo Victora Turnera}

Potrzeba podjęcia gruntownych studiów nad ludzkim doświadczeniem, obecnie tak silnie akcentowana w antropologii (a także w innych naukach o kulturze), była odczuwana i wyrażana już przez niektórych antropologów „prepostmodernistycznych”, zwłaszcza przez Victora Turnera, który wysuwając projekt antropologii doświadczenia, stawiał sobie za cel dotarcie do świata „żywych ludzi", jak lubił pisać, przywołując D.H. Lawrence'a. Za sprawą tego projektu został uznany - by zacytować C. Jasona Throopa - za „jednego z najwybitniejszych w antropologii teoretyków doświadczenia"'.

Idea „antropologii wyzwolonej”, którą Turner wysunął pod koniec życia - choć zarysowywała się w jego myśli znacznie wcześniej - była wymierzona przeciwko generalnemu podejściu antropologii określonemu przez „pojęcia takie jak struktura, równowaga, system”

1 C.J. Throop Articulating Experience, "Anthropological Theory" 2003 No. 3, s. 222.

\section{Grzegorz Godlewski}

- dr hab., prof. nadzw. w Instytucie Kultury Polskiej UW. Zajmuje się antropologiczną teorią kultury i antropologią słowa. Autor książek: Słowo pismo - sztuka słowa. Perspektywy antropologiczne (2008) oraz Luneta i radar.Szkice $z$ antropologicznej teorii kultury (2016). Wiceprzewodniczący Komitetu Nauk o Kulturze PAN. Członek Rady Fundacji „Pogranicze - sztuk, kultur, narodów". 
i skoncentrowanemu na ,tekstach, instytucjach, typach, protokołach, zwyczajach, całym tym «oprzyrządowaniu»"2. Podejście takie, od początku dominujące w antropologii, przyniosło w efekcie - jak to ujął Turner - „systematyczną dehumanizację ludzi jako przedmiotu badań, traktowanych jako nosiciele jakiejś bezosobowej «kultury», jako wosk, w którym odciskają się «wzorce kulturowe»"3. Tymczasem prawdziwe życie zwykłych (podobnie zresztą jak niezwykłych) ludzi nie poddaje się redukcji do „statycznych, atemporalnych modeli" tkwiących w ich głowach ${ }^{4}$. Zwrot, jaki Turner chciał spowodować, miał na celu wyzwolenie antropologii z ograniczeń obowiązującego podejścia i „przywrócenie tej dyscyplinie kontaktu z cielesnym i umysłowym życiem rodzaju ludzkiego"s.

Starania Turnera można uznać za wzorcowy przykład dążenia do wypracowania nowej formuły antropologii, która potrafiłaby dotrzeć do zaniedbywanego dotąd obszaru doświadczenia. Staraniom tym warto przyjrzeć się bliżej, zwłaszcza przeszkodom, na jakie podejmujący je badacz natrafił, nawet jeśli nie udało mu się ich przezwyciężyć - a może właśnie z tego względu. Dla wszystkich bowiem, którzy podążają jego śladem czy choćby tylko zmierzają do tego samego celu, świadomość takich przeszkód ma znaczenie podstawowe, jako że wydają się one nierozerwalnie związane z upragnionym „wyzwoleniem" antropologii. Jest wielce symptomatyczne, że nawet gdy Turnerowi udało się już zidentyfikować właściwy obszar „antropologii wyzwolonej”, nie był w stanie mierzyć się z nim bezpośrednio, lecz wciąż zwracał się ku takim czy innym postaciom ładu kulturowego, co nieuchronnie wyprowadzało go poza ten obszar. I nawet gdy udało mu się wypracować ugruntowaną filozoficznie teorię doświadczenia jako podstawę nowej antropologii, wciąż skupiał się na takich jego formach - dramatach społecznych czy widowiskach kulturowych - które za sprawą swojego zorganizowanego przebiegu, struktury temporalnej bądź zobiektywizowanych artykulacji wyodrębniają się ze „strumienia życia”.

2 V. Turner Foreward, w: R. Schechner Between Theater and Anthropology, University of PennsyIvania Press, Philadelphia 1985, s. xii.

3 V. Turner The Anthropology of Performance, Performing Arts Journal Publications, New York 1986, s. 72.

4 V. Turner Gry społeczne, pola i metafory. Symboliczne działanie w społeczeństwie, przeł. W. Usakiewicz, Wydawnictwo UJ, Kraków 2005, s. 16.

5 V. Turner Foreward, s. xii. 
Może wydawać się zaskakujące, że podjęta przez Turnera próba stworzenia antropologii doświadczenia nie zakończyła się powodzeniem, zważywszy że w trakcie prac nad nowym podejściem coraz wyraźniej dostrzegał on źródła barier epistemologicznych, jakie napotykało badanie form doświadczenia, które „antropologia wyzwolona” miała odsłonić i uchwycić. W jego ostatnich pracach nie brakuje dowodów, że systemowe podejście antropologii traktował nie jako jeden z jej paradygmatów, tylko jako rezultat ogólnej episteme, wyznaczającej podstawy antropologii jako nauki, a być może podstawy całej nauki zachodniej, o ile nie całej zachodniej kultury intelektualnej. Chodzi o „piśmienną episteme”, produkt zaawansowanej piśmienności wykształconej w wyniku rozwoju historycznego kultury zachodniej.

\section{Nachylenie tekstowe}

Teza ta opiera się na stanowisku reprezentowanym przez Teorię Piśmienności, zgodnie z którym pojawienie się pisma i jego rozmaitych użyć doprowadziło do rewolucji nie tylko w sferze komunikacji, ale również w sferze poznania. Pismo zrodziło tekstową formę wypowiedzi, autonomiczny, zdekontekstualizowany dyskurs, który skłania do formułowania myśli w sposób abstrakcyjny i pojęciowy, regulowany przez logikę formalną, w kategoriach ogólnych praw i modeli?. Ten rodzaj dyskursu, wraz ze wszystkimi swoimi wymaganiami i implikacjami, znalazł zastosowanie przede wszystkim w nauce i filozofii, a nawet więcej - ustanowił je i ukształtował. I to za jego sprawą, zdaniem Turnera, ,zachodnia tradycja antropologiczna znacznie oddaliła się od badania - jak to określił D.H. Lawrence - «żywego człowieka» czy raczej «żywego mężczyzny i żywej kobiety». Tradycja ta przejęła sięgające Platona [...] upodobanie Zachodu do wyjaśniania poprzez modele, schematy, paradygmaty, kompetencje, plany, programy, reprezentacje - zakładane, hipotetyczne, konwencjonalne"s.

6 Zob. J. Brockmeier, D. Olson The Literacy Episteme: From Innis to Derrida, w: The Cambridge Handbook of Literacy, ed. by D. Olson, N. Torrence, Cambridge University Press, Cambridge 2009.

7 Zob. J. Goody, I. Watt Następstwa piśmienności, przeł. J. Jaworska, w: Almanach Antropologiczny 2: Oralność/piśmienność, red. G. Godlewski, A. Karpowicz, I. Kurz, A. Mencwel, P. Rodak, Wydawnictwa UW, Warszawa 2007.

8 V. Turner The Anthropology of Performance, s. 84. 
Stąd też orientacja systemowa stanowi podstawowo efekt nachylenia tekstowego, właściwego umysłowi człowieka Zachodu. W kulturze zaawansowanej piśmienności tekst staje się nie tylko wysoko wartościowaną, uprzywilejowaną formą wypowiedzi językowej, ale również modelem myślenia. Piśmienność generuje swoiste kategorie intelektualne, wywiedzione z tekstowego ukształtowania znaczeń i idei; gdy kategorie te zostały uwewnętrznione i wzajemnie uzgodnione, doprowadziły do powstania generalnej tekstocentrycznej postawy poznawczej, która uformowała rdzeń zachodniej racjonalności. Postawa ta, preferująca autonomiczne konstrukcje pojęciowe i ogólnie myśl teoretyczną, stanowi upostaciowanie epistemologii nauki zachodniej i jako taka stała się źródłem i głównym czynnikiem napędowym jej bezprecedensowych osiągnięć. Ich wyjątkowość opiera się przede wszystkim na mocy eksplanacyjnej, jaką dysponuje racjonalność wyrastająca z logiki formalnej, będącej wytworem i instrumentem umysłu piśmiennego, a także na jej zdolności do tworzenia modeli świata, które wykraczają poza możliwe do bezpośredniego zaobserwowania jego przejawy, i osiągania poziomu uniwersalności, obejmującego nie tylko to, co faktycznie stwierdzone, ale również to, co możliwe. Modele takie nie ograniczają się do uporządkowania i uogólnienia tego, co może być ustalone empirycznie hic et nunc, lecz pozwalają na dokonywanie ekstrapolacji zmierzających do określenia tego, co jedynie potencjalne i wyobrażalne, na przewidywanie przebiegu procesów, które nigdy dotąd nie przebiegły. W rezultacie powstaje obraz rzeczywistości przyjmujący postać jej tekstowej reprezentacji, w której to, co postrzegalne (widzialne, słyszalne, dotykalne...), oddawane jest poprzez to, co pojęciowe. Dzięki temu w istocie osiąga się uniwersalny obraz świata, ale za cenę jego tekstualizacji i w konsekwencji dekontekstualizacji.

Ale czy cały świat ma charakter tekstowy? A przynajmniej: czy może zostać ujęty bądź przedstawiony w takiej postaci? Pytania te wydają się czysto retoryczne - ale nie dla reprezentantów nauki „normalnej”, w tym również antropologii „normalnej”. Wielu badaczy kultury, najwyraźniej nie zważając na przełom antypozytywistyczny, jaki dokonał się w nauce, wciąż uznaje podejście nomotetyczne (które pod wieloma względami może być utożsamione z podejściem tekstowym) za jedyną postać prawomocnego poznania naukowego. Skupiają się oni na takich zjawiskach, które dają się zastosować do konstruowania systemów bądź formułowania praw, wszystkie inne traktując jako epifenomeny i wyłączając z obszaru swoich dociekań. Problem nie polega, rzecz jasna, na tym, że ujmowanie jakiegokolwiek zespołu zjawisk w kategoriach systemu lub prawa jest błędne z samej natury; tym, co 
należy uznać za błędne, jest nieodłączne od stanowiska tekstocentrycznego założenie, że tylko zjawiska dające się włączyć w jakiś system lub uczynić przedmiotem jakiegoś prawa zasługują na rozpoznanie i włączenie do wiedzy naukowej. Z drugiej strony nikt nie twierdzi, że zadaniem antropologii jest wytwarzanie dokładnych replik rzeczywistości kulturowej, oddających wiernie sposób istnienia każdego z jej przejawów; gdyby tak miało być, nauka (jakakolwiek nauka, w jakimkolwiek rozumieniu) straciłaby raison d'être jako sposób poznania i zarazem jako instytucja kulturowa. A zatem charakteru poznania antropologicznego nie oddaje w pełni ani logos, ani physis - należy je sytuować w którymś miejscu continuum między tymi biegunami.

Specyfika poznania naukowego to w istocie problem filozoficzny o długiej tradycji, który wymagałby też wszechstronnego rozpatrzenia filozoficznego. Wykracza to poza stawiane tu cele, niech więc wystarczy wskazanie na wzmacnianie się i rozszerzanie przekonania, że w antropologii podejście systemowe wyrastające $\mathrm{z}$ nachylenia tekstowego pozostawia poza swoim zasięgiem poważną część rzeczywistości kulturowej. Co więcej - i co gorsza podejście to powoduje znaczne zniekształcenie obrazu rzeczywistości za sprawą projektowania kategorii i pojęć tekstowych na zjawiska i całe obszary pierwotnie niezorganizowane na sposób tekstowy. Bodaj najważniejszym obszarem tego rodzaju jest sfera potocznego ludzkiego doświadczenia. Jeśli jego rozległe przestrzenie, które dla samych podmiotów nie mają charakteru tekstowego, są przez obserwatorów z zewnątrz ujmowane i interpretowane w kategoriach tekstowych, stanowi to wyraźny przejaw właściwego Zachodowi intelektualizmu, skłaniającego do tego, by zorganizowane tekstowo wzory myślenia rzutować na wszelkie inne ludzkie funkcje i czynności ${ }^{9}$.

Ta generalna kwestia zyskuje szczególną wagę właśnie na polu antropologii. Nachylenie tekstowe oddziałuje na poznanie antropologiczne nie tylko w jego końcowej fazie - w kontekście uzasadnienia: gdy zebrane dane są porządkowane i przedstawiane - ale już w kontekście odkrycia, gdy dane te dopiero się wyłaniają czy też są aktywnie generowane. Innymi słowy, antropolodzy podlegają wpływowi tego nachylenia, nie tylko "pisząc tu”, ale również „będąc tam”"10. Jest oczywiste, że ten, kto sporządza relację pisemną ze swoich badań, napotyka formy i kategorie tekstowe, które można

9 Zob. P. Bourdieu Szkic teorii praktyki poprzedzony trzema studiami na temat etnologii Kabylów, przeł. W. Kroker, Wydawnictwo Marek Derewiecki, Kęty 2007.

10 Zob. C. Geertz Dzieło i życie. Antropolog jako autor, przeł. E. Dżurak, S. Sikora, KR, Warszawa 2000. 
stosunkowo łatwo dostrzec i starać się - choć to już trudniejsze - świadomie przezwyciężyć. Znacznie poważniejszym wyzwaniem jest wykrycie ich oddziaływania podczas badań terenowych, gdy spotkania z innymi nie są zapośredniczone przez pismo, jeśli nie liczyć piśmiennego ukształtowania umysłu antropologa.

Głównym problemem jest więc nie tyle „pisanie kultury”11, ile raczej tekstowe postrzeganie kultury, kultury „żywych ludzi”. Materiał, z którego konstruuje się relację antropologiczną, wytwarzany jest wszak podczas doświadczenia terenowego, jeśli więc zdobyte wówczas dane są od początku ujmowane w postaci tekstowej, to niezależnie od sposobu ich dalszego przetwarzania zachowają one tak zniekształconą postać. Z tego względu starania antropologów postmodernistycznych, aby „pisać inaczej” - łamiąc zasadę dyskursu monologowego, właściwego umysłowi piśmiennemu, i poszukując kontrtekstowych (np. dialogowych czy polifonicznych) sposobów pisania ${ }^{12}-$ przynosiły wątpliwe rezultaty lub wręcz chybiały celu. Starania takie musiały bowiem sprowadzać się do przekładu wiedzy o charakterze tekstowym na formy pozornie lub powierzchownie nietekstowe, w których autorytet antropologa i jego sposobu myślenia, choć przesłonięty i zakamuflowany, w istocie pozostawał nietknięty. Nawet jeśli zaczynały tam przemawiać inne podmioty, tym, kto aranżował ich wypowiedzi i dopuszczał je do głosu, pozostawał antropolog jako autor całości. I nawet jeśli ów antropolog, sprawujący kontrolę nad całą sytuacją, działa w dobrej wierze i dąży do zrzeczenia się swojego autorytetu tekstowego, wraz z gruntującymi go instrumentami intelektualnymi, nigdy nie ma pewności, czy udało mu się wszystkie je wykryć.

A zatem warunkiem wstępnym przezwyciężenia nachylenia tekstowego w badaniach antropologicznych jest samo wykrycie i zidentyfikowanie rozmaitych jego aspektów i przejawów - ale ten pierwszy krok jest najtrudniejszy. Wprawdzie teoretycy piśmienności zrobili wiele, by ujawnić i opisać jej konsekwencje poznawcze ${ }^{13}$, ale badaczom wciąż jest niezwykle trudno

11 Zob. Writing Culture: The Poetics and Politics of Ethnography, ed. by J. Clifford, G. Marcus, University of California Press, Berkeley 1986.

Zob. . . Clifford O autorytecie etnograficznym, przeł. J. Iracka, S. Sikora, w: tegoż Kłopoty z kulturą. Dwudziestowieczna etnografia, literatura i sztuka, KR, Warszawa 2000. dawnictw KUL, Lublin 1992; J. Goody Poskromienie myśli nieoswojonej, przeł. M. Szuster, PIW, Warszawa 2011; D. Olson Papierowy świat. Pojęciowe i poznawcze implikacje pisania i czytania, przeł. M. Rakoczy, Wydawnictwa UW, Warszawa 2010. 
zdystansować się od zasad i reguł, które ustanowiły naukę - w jedynej postaci, w jakiej ją znają - i wciąż wydają się ją legitymizować. Jak prowadzić badania, nie stosując wszystkich procedur - takich jak selekcja i organizacja danych, uogólnianie, budowanie modeli i praw, przewidywanie przebiegu procesów - które w naszej kulturze odróżniają naukę od innych rodzajów poznania? Głównym źródłem tych procedur jest piśmienność (wraz ze swoim najbardziej zaawansowanym wytworem, podejściem tekstowym), stanowiąca technologię umysłową, której przypisuje się najwyższy status kulturowy; co więcej, stanowi ona część naszego wyposażenia intelektualnego, inherentny składnik umysłu zachodniego. Wydaje się więc, że nie można się jej po prostu pozbyć, jak okularów z naszego nosa - by sparafrazować Ludwiga Wittgensteina - jako że tkwi ona w nas, jak soczewki naszych oczu.

Nachylenie tekstowe jest tak głęboko zakorzenione w umyśle naukowym, że nikomu nie uda się wyeliminować go na mocy samej świadomości, że nachylenie takie istnieje, i postanowienia, by je odrzucić. Zostaliśmy ukształtowani przez nasze wysoce piśmienne instytucje, zwłaszcza szkołę i akademię, jako istoty tekstocentryczne, niepodobna więc, byśmy po prostu cofnęli się do stanu przedtekstowego, odzyskując „naturalne”, ,pierwotne” nastawienie do świata. O ile wydaje się możliwe, choć niezwykle trudne, wykroczenie poza nasz intelektualny status quo, o tyle jest nie do pomyślenia, byśmy byli zdolni wrócić do status quo ante. Nigdy już nie staniemy się niewinni (umysłowo).Trzeba więc sięgnąć po pewne specjalne środki, mogące pomóc nam w przezwyciężeniu nachylenia tekstowego z wnętrza naszego piśmiennego stanu umysłu.

\section{Ku kontrnauce}

Ale by wybrać lub stworzyć takie środki, najpierw należy określić cel, jaki ostatecznie chce się osiągnąć. Bo czyż zamierzone wyzwolenie antropologii spod obowiązujących wymagań nauki „normalnej” nie prowadzi nieuchronnie poza granice nauki w jakimkolwiek rozumieniu? A może jest do pomyślenia ustanowienie jakiegoś nowego rodzaju nauki niezdefiniowanej w kategoriach tekstowości - jakiejś „antynauki” czy „,kontrnauki” (ale nie „prenauki”) - która mimo to zachowywałaby status uprzywilejowanej formy poznania? Nawet najbardziej fundamentalna krytyka nauki powinna odróżniać tę szczególną postać nauki, jaka rozwinęła się w nowożytnej kulturze zachodniej, od samej idei nauki jako pewnej wartości kulturowej. Pierwsza jest z natury historyczna i, niezależnie od swoich osiągnięć, jedynie 
relatywna, jeśli chodzi o przyjmowane założenia i stosowane metody; jako taka nie jest więc ani absolutna, ani wieczna. Drugą - obejmującą pierwszą jako szczególny przypadek - można określić jako odrębny rodzaj ludzkiej aktywności, która może być różnorako definiowana, ale, najogólniej rzecz ujmując, stanowi formę poznania wykraczającego poza miary użyteczności, instrumentalności i funkcjonalności, poszukiwanie wiedzy stanowiące aktywność autoteliczną. Nauka w tym drugim rozumieniu nie daje się sprowadzić do wytworu jakiegokolwiek konkretnego procesu historycznego, choć zarazem nie można jej uznać za zjawisko uniwersalne. Istnieją wszak kultury, w których tego rodzaju aktywność się nie wykształciła, zwłaszcza w zorganizowanej i zinstytucjonalizowanej postaci; gdy jednak już się wyłoni, pojawia się nowy wymiar istnienia człowieka w świecie, wzbogacający repertuar form ludzkiego uczestnictwa w życiu i rzeczywistości. A zatem nauka w tym uogólnionym, transkulturowym sensie stanowi siłę kulturotwórczą, zdolną do poszerzania horyzontów świata człowieka, i jako taka zawsze zasługuje na wsparcie i ochronę.

Antropologia jako nauka wyrosła z historycznej ewolucji nauki zachodniej (ściśle rzecz biorąc: z ewolucji nauki o ewolucji), podstawowo jednak zawdzięcza swoje istnienia ogólnej idei poznania, która nie ogranicza się do żadnej historycznej postaci nauki. Przyjmując, że istotą antropologii jest ciągłe zmaganie się z problemem „kultury i kultur” bądź, by sięgnąć do Rousseau, „badanie człowieka” przeciwstawione „badaniu ludzi”, trudno zaprzeczyć, że kwestie tego typu mogą pojawić się jedynie w obrębie ideału wiedzy, która przekracza poziom bezpośrednich potrzeb i zastosowań. Ale też równie trudno utrzymywać, że sama natura tego problemu wymaga, aby rozwiązując go, stosować jakiekolwiek konkretne podejście. Zapewne dlatego właśnie krytyka nauki, nasilająca się w ostatnich dekadach w antropologii czy to rozwijająca idee Tunera, czy to wyrastająca z innych podstaw - często prowadzi do przekonania, że jakaś inna postać nauki jest możliwa czy wręcz konieczna ${ }^{14}$. W wielu przypadkach ci, którzy reprezentują takie stanowisko, pobudzani są przez samą chęć uchwycenia takich aspektów rzeczywistości kulturowej - najczęściej odnoszących się do doświadczenia - które dotąd znajdowały się poza zakresem badań, i nie starają się o poważniejsze uzasadnienie teoretyczne swoich inicjatyw. Jednak w zachodniej tradycji intelektualnej można dostrzec pewną linię myślicieli, którzy otwarcie lub

14 Zob. M. de Certeau Wynaleźć codzienność. Sztuki działania, przeł. K. Thiel-Jańczuk, Wydawnictwo UJ, Kraków 2008. 
implicite odrzucali tekstowy paradygmat nauki i poszukiwali alternatywnych dróg poznania naukowego - by wspomnieć tylko dwa przykłady, szczególnie ważne dla współczesnej antropologii: Wilhelma Diltheya, z jego oryginalną koncepcją doświadczenia ${ }^{15}$, i Maurice'a Merleau-Ponty'ego, z jego inspirującą fenomenologią kulturową ludzkiego świata ${ }^{16}$. I jeszcze jeden, nowszy przykład: Roy Harris, który w swoich ostatnich pracach dowodzi, że racjonalność w przyjętym rozumieniu wyrasta z piśmiennego nacechowania kultury europejskiej, a zatem nie może być uznana za uniwersalną i należy dopuścić możliwość istnienia innych racjonalności, opartych na innych podstawach ${ }^{17}$.

Ale nawet jeśli istnieją poważne koncepcje otwierające drogę do alternatywnych postaci nauki, są one zbyt wątłe, aby ugruntować rozwinięte ramy teoretyczne dla nowej antropologii, wyzwolonej spod reżimu tekstowości. Ponadto należy wziąć pod uwagę, że taka antropologia winna być wolna od jakichkolwiek regulacji o charakterze paradygmatycznym, jako że paradygmaty w nauce z definicji są systemami o charakterze tekstowym. Dlatego o projektach alternatywnych należy myśleć raczej w kategoriach strategii niż systemów i, obmyślając je, trzeba strzec się dążenia do wypełnienia kryteriów kompletności i wewnętrznej spójności; wystarczy, jeśli projekty takie będą kierowane przez pewne ogólne wektory. W przedsięwzięciach tych można czerpać inspiracje teoretyczne z zewnątrz, ale jedynie w najbardziej ogólnym sensie. Przykładowo, odnosząc się do koncepcji wskazanych przed chwilą: od Diltheya warto przejąć przestrogę, by żywe doświadczenie ujmować jedynie w kategoriach wywiedzionych z niego samego; od Merleau-Ponty'ego - przekonanie o pożytkach płynących z kulturowego wariantu fenomenologicznej epoché; od Harrisa - zachętę do poszukiwania alternatywnych miar racjonalności. Tyle - i niewiele więcej.

\section{Luneta i radar}

Biorąc to wszystko pod uwagę, należy stwierdzić, że strategie posttekstowego, a zatem kontrtekstowego podejścia badawczego powinny być formułowane

15 Zob. W. Dilthey Budowa świata historycznego w naukach humanistycznych, przeł. E. Paczkowska-Łagowska, słowo/obraz terytoria, Gdańsk 2004.

16 Zob. M. Merleau-Ponty Fenomenologia percepcji, przeł. M. Kowalska, J. Migasiński, Fundacja Aletheia, Warszawa 2001.

17 Zob. R. Harris Racjonalność a umysł piśmienny, przeł. M. Rakoczy, Wydawnictwa UW, Warszawa 2014; tegoż After Epistemology, Bright Pen, Gamlingay 2009. 
w kategoriach epistemologicznych, nie zaś metodologicznych, a ich opis może być jedynie przybliżony czy wręcz metaforyczny. Przyjrzyjmy się jednej z takich strategii, którą proponuję nazwać „strategią radaru”, przeciwstawiając ją „strategii lunety"18. Ta ostatnia, właściwa antropologii paradygmatycznej, kładzie nacisk na udział aktywnych, nawet inwazyjnych narzędzi poznawczych we wszystkich fazach procesu badawczego. Korzystający z niej badacz opiera się na przyjętej z góry ogólnej teorii, która orzeka a priori, co w wybranej sferze rzeczywistości istnieje, co może być przedmiotem badania i na nie zasługuje, za pomocą jakich narzędzi i w jakiej skali i perspektywie może być ujmowane. Wyniki uzyskiwane w ten sposób są w pewnej mierze przewidywalne, implikuje je bowiem przyjęty program badawczy, oparty na wyraźnie zarysowanym, zorganizowanym i ustrukturyzowanym obrazie badanego obszaru i przesądzający o jego charakterze bądź istocie. System tkwiący w umyśle badacza poprzedza więc rzeczywistość i ją definiuje. Takie postępowanie badawcze, którego figurą jest luneta, stanowi w istocie procedurę tekstową.

Strategia radaru odwraca ten porządek. Badacz nie odwołuje się w punkcie wyjścia do żadnej paradygmatycznej teorii, lecz, działając jak tradycyjny radar, przyjmuje otwartą postawę wobec rzeczywistości: po prostu zwraca się w pewnym kierunku i wysyła otwarte pytania, jak fale radiowe, zachowując gotowość do przyjmowania wszelkich napływających sygnałów, niezależnie od ich charakteru i źródła, w postaciach, w jakich mu się jawią. Powstający w ten sposób obraz będzie nie tylko bardziej wszechstronny, ale również w mniejszym stopniu zapośredniczony i uformowany przez wcześniejsze założenia i oczekiwania. Gdy badacz nie postrzega rzeczywistości jak przez lunetę, a więc w ramach zakreślonych przez przyjęty program czy paradygmat badawczy, lecz organizuje swoje podejście na podobieństwo radaru, otwierając się na formy, w jakich rzeczywistość ta uobecnia się doświadczającemu jej człowiekowi, wówczas relacja między tym, co ogólne, a tym, co szczegółowe, schodzi na dalszy plan, ustępując miejsca relacji między tym, co pierwotne, a tym, co pochodne, nadbudowane, skonstruowane. Oznacza to, że wiedza naukowa przestaje być podporządkowana zasadom logiki formalnej, będącej produktem i instrumentem racjonalności uformowanej przez umysł piśmienny, a zaczyna podlegać „logice pierwotności”, immanentnej logice kultury, która - zgodnie z koncepcją Ernsta Cassirera - określa, w jaki sposób złożone formy kulturowe wyrastają z dyspozycji tkwiących w pierwotnych zjawiskach

18 Zob. G. Godlewski Luneta i radar. Szkice z antropologicznej teorii kultury, Wydawnictwa UW, Warszawa 2016. 
kulturowych i są przez nie generowane ${ }^{19}$. Logika taka nie ma charakteru tekstowego, a mimo to może służyć jako instrument zdyscyplinowanej rekonstrukcji rzeczywistości kulturowej.

Tak scharakteryzowana strategia przypomina pod wieloma względami podejście fenomenologiczne, w tym zwłaszcza kulturową formę epoché, którą również z innych powodów należałoby rekomendować jako przydatne wsparcie epistemologiczne dla ,antropologii wyzwolonej”. Ale strategia ta wykracza poza metodę epoché, jako że wymaga nie tylko powstrzymania się od orzekania z góry, co i jak istnieje, ale również zawieszenia przyjętych sposobów orzekania i innych czynności intelektualnych o charakterze tekstowym. Antropologia powinna zatem wziąć w nawias nie tylko wszelkie konkretne założenia dotyczące rzeczywistości kulturowej, ale również wszelkie nacechowane tekstowo kategorie, jakich używa się, przyjmując cokolwiek na temat czegokolwiek. Innymi słowy, zastosowanie podejścia fenomenologicznego w antropologii implikuje eliminację nachylenia tekstowego jako cechy definiującej podmiotu poznającego.

Strategia radaru znajduje swoją prefigurację w stanowisku Victora Turnera, który twierdził, że „każde poważne studium człowieka musi podążać za nim wszędzie tam, dokąd [on - przyp. G.G.] idzie"20. Stwierdzenie to należy rozumieć nie tylko w dosłownym, przestrzennym sensie, ale również metaforycznie: antropolog powinien przyjmować obraz świata, jaki mają badani przez niego ludzie, jako wyznacznik lub przynajmniej współczynnik jego własnego obrazu ich świata. Oznacza to, że w antropologii fenomenologia percepcji musi porzucić swoje roszczenia do uniwersalności i poddać się relatywizmowi kulturowemu; w konsekwencji antropologiczne badanie innych światów powinno kierować się tym, w jaki sposób świat ten jest postrzegany przez tych, którzy go zamieszkują i czynią swoim światem. A zatem tym, co antropolog powinien brać pod uwagę w pierwszej kolejności, jest nie tyle fenomenologia świata Innych, ile raczej właściwa Innym fenomenologia ich świata ${ }^{21}$. Spełnienie tego nakazu - niezależnie od tego, jak jest on wymagający - wydaje się podstawowym warunkiem przezwyciężenia dominacji poznawczej nieodłącznej od tekstowo nacechowanej antropologii;

Zob. E. Cassirer Logika nauk o kulturze, przeł. P. Parszutowicz, Wydawnictwo Marek Derewiecki, Kęty 2011.

21 Zob. Things as They Are: New Directions in Phenomenological Anthropology, ed. by M. Jackson, Indiana University Press, Bloomington 1996. 
tekstocentryzm jest bowiem w istocie jednym z oblicz etnocentryzmu. „Żywy człowiek" powinien być gospodarzem w własnym świecie, nawet wówczas gdy świat ten jest wizytowany przez (zawodowego) przybysza z daleka. W tym przypadku profesjonalizm polega na zawieszeniu profesjonalnej wiedzy o kulturze i kulturach, nie tylko na poziomie treści, ale również w odniesieniu do organizujących ją kategorii tekstowych.

\section{Zakwestionować tożsamość, zakwestionować autorytet}

Jest to w istocie trudne zadanie: zrzec się swoich profesjonalnych kompetencji, aby w ten sposób pozbyć się tego, co zwyczajowo stanowi o tożsamości antropologa, i podjąć próbę zredefiniowania tej tożsamości, oparcia jej na odmiennym rozumieniu roli badacza. Stawką w tej grze jest jednak nie tylko tożsamość, ale również autorytet: jak w tej sytuacji uzasadnić epistemologiczne uprzywilejowanie antropologa, jego szczególny sposób obecności nie wówczas, gdy "pisze tu”, w tekście antropologicznym, gdzie autorytet manifestuje się w postaci autorstwa ${ }^{22}$, ale gdy "jest tam”, w terenie, gdzie badacz funkcjonuje jako „zawodowy obcy”? Jak tego dokonać, zważywszy że legitymizacja roli antropologa powinna mieć zastosowanie zarówno do niego samego, jak i do tych, których bada? A może zawieszenie profesjonalizmu powinno prowadzić do rezygnacji z jakiegokolwiek autorytetu, z jakiegokolwiek uprzywilejowania poznawczego? Z drugiej zaś strony - jak wykryć wszystkie środki i nastawienia, które zamykają drogę do doświadczenia Innych? Może się wydawać, że są to przeszkody nie do pokonania; o ile jednak uznać, że cel jest naprawdę wart zachodu - ta „misja niemożliwa” powinna zostać podjęta.

Ale jeśli, wbrew wszystkim tym trudnościom, komuś uda się, w taki czy inny sposób, zyskać dostęp, choćby tylko częściowy i ograniczony, do tego, jak swój świat postrzegają Inni - to jeszcze nie wystarczy. Antropolog potrzebuje bowiem jakiejś ramy poznawczej, która pozwoliłaby mu ustabilizować osiągnięte podejście badawcze i uporządkować zdobyte dzięki niemu dane.

W podobnym kontekście Victor Turner zalecał wykorzystanie „współczynnika humanistycznego", kategorii poznawczej zaproponowanej przez Floriana Znanieckiego ${ }^{23}$. Kategoria ta, choć pierwotnie przeznaczona dla socjologii, z czasem zaczęła być stosowana w innych naukach o kulturze, jako że pozwala dobrze uchwycić specyfikę podejścia epistemologicznego do ludzkiego

Zob. J. Clifford O autorytecie etnograficznym; C. Geertz Dzieło i życie... 
świata, zwłaszcza relację między poznającym i poznawanym. Relacji tej nie należy ujmować tak, jak czyni się zwykle w innych naukach, gdzie to, co poznawane, ulega obiektywizacji i zostaje całkowicie podporządkowane poznającemu. W badaniach antropologicznych rozdzielenie takie i uznanie poznającego za stronę czynną, a tego, co poznawane, za stronę bierną, oznaczałoby pominięcie faktu, że w tym przypadku tym, co badane, są inne istoty ludzkie, których postrzeganie, rozumienie i wartościowanie ich świata powinny zostać co najmniej wzięte pod uwagę przez badacza tego świata. Nie chodzi jednak o to, aby te dwie perspektywy zostały połączone, aby badacz miał postrzegać świat z pozycji badanych ludzi; nawet gdyby udało się do tego doprowadzić, nie byłoby to pożądane, gdyż jaki byłby pożytek z nauki dającej się sprowadzić do tego, co oczywiste dla ludzi w ich „światach przeżywanych"? Badanie ludzkiej rzeczywistości powinno raczej przyjąć podejście dwuperspektywiczne, polegające na ujmowaniu tej rzeczywistości z wyniesionego, uprzywilejowanego metapoziomu naukowego i zarazem z poziomu ludzi w niej żyjących, ich doświadczenia i rozumienia świata.

Wartość dodana współczynnika humanistycznego w antropologii polega na tym, że jego stosowanie pozwala przezwyciężyć utrwaloną opozycję ujęć emicznego i etycznego. Ich zdecydowane, kontradyktoryczne rozróżnienie wydaje się kolejną manifestacją nachylenia tekstowego, skłaniającego do ostrego rozdzielania odmiennych punktów widzenia i traktowania ich jako odrębne systemy, z których każdy jest autonomiczny i spójny wewnętrznie, jak dopracowany i domknięty tekst. Tymczasem dla antropologa „być tam” to pozostawać w ciągłej relacji z innymi ludźmi, w której dochodzi do wzajemnego przenikania się perspektyw, dynamicznej gry dystansu i bliskości, zmienności czasowej - i wszystkie te czynniki winien on brać pod uwa$\mathrm{gę}^{24}$. Dlatego współczynnik humanistyczny nie powinien tu być stosowany w sposób statyczny, jak luneta o ustalonych parametrach, lecz elastycznie, jak mobilny radar, nieustannie przystosowujący się do nowych, nieprzewidywalnych sytuacji.

Nie oznacza to, że taka strategia pozwala wszystkie sygnały napływające z badanej rzeczywistości odbierać, postrzegać i rozumieć w taki sam sposób jak jej uczestnicy. Nie jest możliwe - i po prawdzie byłoby bezcelowe - wyeliminowanie dystansu między badającym a badanymi dopóty, dopóki ten pierwszy zachowuje swoją rolę, tak czy inaczej zdefiniowaną. Strategia radaru

24 Zob. K. Hastrup Getting It Right: Knowledge and Evidence in Anthropology , Anthropological Theory" 2004 No. 4. 
nie zapewnia żadnej stałej pozycji, która oferowałaby bezpośredni dostęp do Innych i ich świata; przyjmuje raczej postać ciagłego ruchu ku nim, podczas którego wyłaniają się coraz to nowe przeszkody, które próbuje się usunąć, co jest tym trudniejsze, że niektóre z nich pojawiają się w umyśle badacza, stanowiąc często przejawy nachylenia tekstowego.

\section{Etnografia jako (auto)terapia}

Sytuacja taka pociąga za sobą konsekwencje dwojakiego rodzaju. Po pierwsze, badania prowadzone zgodnie ze strategią radaru powinny być traktowane podstawowo jako forma praktyki; po drugie, praktyka ta, mająca na celu intensywne zaangażowanie w kontakty z ludźmi w ich świecie, wymaga nie tyle umiejętności profesjonalnych, ile raczej pewnych własności (a czasem też umiejętności) osobistych, czysto ludzkich. Żadna metoda naukowa nie zagwarantuje badaczowi dostępu do tego, w jaki sposób inni ludzie postępują w swoim świecie i go traktują; w tej kwestii w większym stopniu można polegać na osobistym doświadczeniu w nawiązywaniu kontaktów z ludźmi, w obcowaniu z nimi, niż na profesjonalnym wykształceniu czy wyspecjalizowanej wiedzy. Tym bardziej, że badacz jako badacz jest nieuchronnie osobą o nachyleniu tekstowym, które słabnie, gdy podejmuje on starania o zawieszenie - na podobieństwo fenomenologicznej epoché - wszystkiego, w co wykształcenie i wiedza go wyposażyły, aby postępować jak zwykły człowiek, doświadczający tego, co spotyka go w codziennym życiu. Nawet jeśli trudno przypuszczać, by cel ten mógł zostać w pełni osiągnięty, warto do niego dążyć, ponieważ zbliżanie się do niego zbliża do doświadczenia innych ludzi i zwiększa prawdopodobieństwo, że będzie ono jawiło się badaczowi przyjmującemu tu rolę towarzyszącego obserwatora - jako doświadczenie, niezapośredniczone przez kategorie tekstowe.

Dążenie do tego celu może przebiegać w dwóch kierunkach: na zewnątrz, ku rzeczywistości cudzego doświadczenia, do którego chce się dotrzeć, i do wewnątrz, drogą przeciwstawiania się kategoriom poznawczym, zwłaszcza wytworzonym przez nachylenie tekstowe, które utrudniają dotarcie do tego doświadczenia.

Podążając w pierwszym z tych kierunków, należy przyjąć wskazania wcześniej tu rekomendowane, przede wszystkim "podążając za człowiekiem wszędzie tam, dokąd idzie", dystansując się wobec profesjonalnej wiedzy i kategorii antropologicznych, zwłaszcza nacechowanych tekstowo, i starając się stosować w badaniach strategię radaru. Są to jednak wskazania w gruncie 
rzeczy metateoretyczne, formułujące bardzo ogólne zasady postępowania. Wydaje się więc niezbędne, by nieco bliżej określić obszary i wymiary badanej rzeczywistości, które mogą zapewnić dostęp do doświadczenia Innych. Najogólniej rzecz ujmując, można oczekiwać, że dotrze się do „żywego człowieka” za pośrednictwem tego, co czyni go „żywym”.

Praktyczne życie wypełnione jest, rzecz jasna, głównie przez praktyki. Jak twierdzą teoretycy praktyk, zwłaszcza Pierre Bourdieu, stanowią one taki rodzaj ludzkiej aktywności, którego przejawy zawsze pozostają w pewnej mierze nieprzejrzyste: praktyki zasadniczo nie są kierowane czynnikami intelektualnymi, nie mogą być redukowane do modeli ani przez nie reprezentowane i w konsekwencji stawiają opór rekonstrukcji teoretycznej, a więc tekstualizacjii25. Mają charakter zwyczajowy, nawet rutynowy; opierają się na pewnych schematach, ale nie stosują się do żadnych ścisłych reguł. Dlatego przebieg praktyki jest nieodgadniony dla postronnego obserwatora, musi więc być śledzony w miarę, jak się rozwija, i oddawany jako zjawisko dziejące się w czasie. Praktyki są emergentne, nigdy więc nie są w pełni przewidywalne, aktualizując się we wzajemnych interakcjach z sytuacją, środowiskiem i innymi ludźmi, z rozmaitymi okolicznościami i wykorzystywanymi materiałami; tym, co decyduje o ich przebiegu, nie są plany, cele czy intencje, ale pamięć, wprawa, ciało, zmysły, emocje, nastroje, skłonności, intuicje. A wszystko to są jakości, które stawiają opór tekstualizacji i w istocie nie poddają się badaniu w ścisłym sensie, zdystansowanemu i niezaangażowanemu; nie da się ich zobiektywizować w ogólnych pojęciach, interpretować w abstrakcyjnych kategoriach, rekonstruować jako koherentnych i logicznie zorganizowanych całości. Należy raczej przyjmować wobec nich postawę wyznaczaną przez takie czasowniki, jak: towarzyszyć, podążać, asystować, angażować się, uczestniczyć, przyłączać się, podzielać. Postawa taka nie doprowadzi nigdy do pełnej identyfikacji z Innymi, ale pozwala maksymalnie się do nich zbliżyć, nigdy jednak nie zacierając oddzielającej od nich różnicy.

Tyle na temat doświadczenia Innych dostępnego - w ograniczonym stopniu - poprzez ich praktyki kulturowe, poprzez sposoby ich działania w świecie. Inną stroną tej kwestii są sposoby postrzegania świata, będące wszak integralnym składnikiem jego doświadczania. Jak przekonuje Tim Ingold, postrzeganie rzeczywistości również znajduje odzwierciedlenie w praktykach, a przynajmniej może być z nich wywnioskowane, bo przecież obraz świata nie powstaje wyłącznie w umysłach ludzi, lecz wyłania się z ich interakcji ze

Zob. P. Bourdieu Szkic teorii praktyki... 
środowiskiem, ze sposobów oddziaływania na nie i skutków jego oddziaływań ${ }^{26}$. Tak czy inaczej, dostęp do postrzegania oferowany przez praktyki może być jedynie pośredni i częściowy. Nie ma sposobu, by wniknąć w cudze życie wewnętrzne, by postrzegać cudze postrzeżenia. Ale Inni mogą sami udostępnić je antropologowi.

"Żywi ludzie" są wszak również istotami refleksyjnymi, zdolnymi do wytwarzania sensów, świadomymi swoich doświadczeń i powiązanych z nimi stanów wewnętrznych. I są w stanie udzielić im głosu - najzupełniej dosłownie: poprzez mówienie. Komunikacja w zbiorowości na temat doświadczeń, na temat odczuć dotyczących świata przeżywanego sprawia, że stają się one wspólne i trwałe, i uczestniczy w tym, co Peter Berger i Thomas Luckmann określili jako społeczne tworzenie rzeczywistości ${ }^{27}$. I właśnie poprzez ludzkie słowa - wypowiedzi, narracje, relacje, komentarze, uwagi, ekspresje - antropolog może zyskać pewne wyobrażenie o „właściwej Innym fenomenologii ich świata". Nie chodzi tu o uzyskanie potrzebnych informacji dzięki wywiadom z informatorami jako jednej z metod badania etnograficznego. Metoda ta stanowi klasyczny przykład podejścia tekstowego, jako że zmusza badanego do zdystansowania się wobec własnych doświadczeń czy odczuć i mówienia o nich jako czymś zewnętrznym, uprzedmiotowionym i zobiektywizowanym, osadzonym w autonomicznym, zdekontekstualizowanym dyskursie. W ten sposób uzyskuje się jedynie artefakty, często luźno związane z doświadczeniem i w istocie współwytwarzane przez badacza. Tymczasem tu chodzi o to, by słuchać tego, co ludzie mówią do siebie nawzajem i między sobą, spontanicznie, bez narzuconej im ramy dyskursywnej, nie w intencji przekazania znaczenia swoich doświadczeń, tylko jako ich symptomy, sygnały czy oznaki. Walka z nachyleniem tekstowym nie powinna prowadzić do wyeliminowania wszelkich danych językowych. Język „żywych ludzi” sam też jest żywym językiem, który nie poddaje się tekstualizacji.

Starania o dotarcie do doświadczenia i postrzegania świata Innych powinny też być zwrócone do wewnątrz, przeciwko tekstocentryzmowi umysłu badacza. Prócz wszystkiego, co już na temat zostało powiedziane, należy zwrócić uwagę jeszcze na jedno. Otóż nachylenie tekstowe jest w nas tak głęboko zakorzenione, że jest nie do pomyślenia, aby pozbyć się go od wewnątrz, po prostu podejmując taką decyzję. Nawet jeśli ktoś dostrzega jego

\footnotetext{
26 T. Ingold The Perception of the Environment: Essays on Livelihood, Dwelling and Skill, Routledge, London 2000.

27 P. Berger, T. Luckmann Społeczne tworzenie rzeczywistości, przeł. J. Niżnik, PIW, Warszawa 1983.
} 
istnienie i uznaje potrzebę jego przezwyciężenia, niepodobna ujawnić i rozpoznać wszystkie jego aspekty i konsekwencje jedynie poprzez autoanalizę, dotyczącą używanych kategorii, pojęć i metod. Postępowaniu takiemu powinna towarzyszyć nieustanna wrażliwość na potencjalne zagrożenia wynikające z zakłóceń poznawczych powodowanych przez nachylenie tekstowe. Większość z nich może zostać wykryta tylko praktycznie, w trakcie pracy badawczej, gdy antropolog napotyka zjawiska, które stawiają opór narzędziom i środkom stosowanym w celu ich uchwycenia. A biorąc pod uwagę, że skala zróżnicowania zjawisk kulturowych jest w istocie niewyczerpana, proces ten może nie mieć końca. Oznacza to, że cel, o który tu chodzi, przezwyciężenie nachylenia tekstowego, nie będzie nigdy w pełni osiągnięty; może się okazać, że możliwe jest jedynie dążenie do niego, nieustanne, bez ostatecznego finału.

Sytuacja ta przypomina zadanie, jakie stawiał sobie Ludwig Wittgenstein w swoich późnych pracach. Jego dociekania filozoficzne - w tym zwłaszcza Dociekania filozoficzne - miały na celu krytykę przyjętego w filozofii podejścia do języka, które w znacznej mierze można utożsamić z nachyleniem tekstowym. Sposób prowadzenia tych dociekań przez filozofa - mających torować drogę do nowego podejścia, obejmującego głównie realne użycia języka w życiu codziennym - można traktować jako terapię filozofii i zarazem autoterapię samego filozofa. Dzieło Wittgensteina zdaje się wskazywać, że terapia ta nie może doprowadzić do pełnego wyzdrowienia i powinna być traktowana jako niekończący się proces. Trudno nie zauważyć, że strategia opisywana i rekomendowana w niniejszym tekście pod wieloma względami wykazuje podobieństwo do przedsięwzięcia Wittgensteina. Dlatego warto, a może nawet należy sięgać do jego prac, poszukując rozwiązań problemów napotykanych w trakcie stosowania tej strategii. Ale w tym miejscu możliwość tę mogę tylko zasygnalizować.

W konkluzji należy podkreślić to, na co kładą nacisk badacze praktyk: badania „żywych ludzi”, ich doświadczenia i postrzegania świata, same powinny przyjmować postać praktyk. Oznacza to, że badania antropologiczne, stawiające sobie za cel uchwycenie doświadczenia jako doświadczenia, praktyki jako praktyki, postrzegania jako postrzegania, powinny kierować się nie logiką formalną, a więc tekstową, ale logiką praktyki, stosowaną w interakcji ze zmieniającymi się wciąż procesami i formami życia. Nie ma wątpliwości, że badaczowi nigdy nie uda się dotrzeć do doświadczeń i obrazów świata Innych, ale nie ma też wątpliwości, że może zbliżyć się do nich znacznie bardziej jako „żywy antropolog" niż jako uczony o nachyleniu tekstowym. 


\section{Abstract}

\section{Grzegorz Godlewski}

UNIVERSITY OF WARSAW

Beyond the Textual Bias, Towards Pretextual Experience: Therapeutic Guidelines

This article indicates possible ways of researching cultural reality as a dimension of experience. Victor Turner's project of the anthropology of experience opens up such possibilities, though Turner also encountered serious obstacles such as the systemic approach, which is binding in the discipline. This approach is rooted in the textual bias that dominates Western science and culture - a tendency that results from advanced literacy and that leads to the textualization of reality, thus eliminating or distorting many of its manifestations. Overcoming this tendency necessitates breaking with the binding patterns of scientific thinking and working towards the creation of some kind of counter-science. The theoretical initiatives that emerged from the theory of practice and the cultural phenomenology can be helpful here, although approaching the cultural experience of the Other demands constant efforts on the researcher's part. Godlewski suggests, however, that to identify and eliminate manifestations of text-centrism in one's own mind can be a form of cognitive self-therapy.

\section{Keywords}

anthropology of experience, cultural phenomenology, counter-science, textual bias, cultural practices, theory of literacy 